\title{
Középkori gyermekgondozási szokások és eszközök korabeli képzőmüvészeti alkotások tükrében $^{1}$
}

\author{
MUCSINÉ ISASZEGI IRINA
}

\begin{abstract}
A középkor gyermekszemléletével kapcsolatban számos - sok esetben egymástól jelentös mértékben eltérö - irányzat alakult ki az utóbbi évtizedek során. A korral foglalkozó, különböző nézeteket valló szakemberek eltérö módon határozzák meg a korabeli szülō-gyermek kapcsolat minöségét és a gyermekek helyét a társadalomban. A rendkivül részletgazdag középkori képzömüvészeti alkotások bepillantást engednek a korabeli csecsemök és kisgyermekek életébe, mintegy tükrözve a kor gyermekszemléletét. Ezen müalkotások révén megismerhetünk olyan gondozási szokásokat, melyek napjainkban már nem képezik részét a gyakorlatnak, de találkozhatunk ma is használatos eszközök középkori elödeivel is. Kutatásom során számos olyan festményre bukkantam, melyen a gyermekek jólétét, biztonságát és megnyugtatását szolgáló tárgy, illetve gyakorlat került ábrázolásra. Mindez pedig a társadalom gyermekekkel szembeni pozitív attitüdjére enged következtetni, rávilágitva arra, hogy a korabeli felnöttek igyekeztek megfelelö módon gondoskodni utódaikról.
\end{abstract}

Kulcsszavak: középkor, gyermekszemlélet, gyermekábrázolás, gyermekgondozás, festészet

A középkori gyermekek helyzetével, a középkori társadalom gyermekszemléletével kapcsolatban többféle nézőpont, irányzat alakult ki az elmúlt évtizedek alatt. Ennek oka egyrészt a felhasznált források sokaságában, másrészt azok értelmezésében keresendő. A korral foglalkozó történészek között megoszlanak a vélemények arról, hogy a középkori ember értékes, értéktelen vagy szükséges rossznak tekintette-e a gyermekkort a felnőtté válás folyamatában (Pukánszky, 2001). A magyarázatokban rejlő különbség a forrásanyagok eltérő módon történő értelmezésében, a szerzők sokszor igencsak különböző szemléletében keresendő, és nagymértékben meghatározza az, hogy az adott kutató a kor társadalmának, attitűdjeinek megítéléséhez milyen viszonyítási alapot használt.

Számos olyan szakirodalmi mü ismert, mely ezen témával és korral foglalkozik. Míg egyes szerzők - így Philippe Ariès, Edward Shorter és Lloyd deMause - a diszkontinuitás elméletére építik álláspontjukat és egy korokon átívelő, fo-

\footnotetext{
${ }^{1}$ A tanulmány az alábbi szakdolgozat alapján készült: Mucsiné Isaszegi Irina (2015): Gyermeknek lenni a sötét (?) középkorban.
}

lyamatosan fejlődő kapcsolatot tételeznek fel a szülők és gyermekek között, addig Shulamith Shahar, és Linda Pollock a kontinuitás elméletét képviselve egy szociobiológiai alapokon nyugvó, örök elemekkel rendelkező, folytonos kapcsolatot tételez fel (Golnhofer és Szabolcs, 2005; Endrödy-Nagy, 2013; 2015). A középkori felnőttek viselkedésére többen, többféle magyarázatot adtak, gazdag forrásanyagokra támaszkodva eltérő módon értelmezték és indokolták a gyermekekkel szembeni hozzáállást, a családok működését, valamint a gyermekek helyét a családokban, illetve a társadalomban.

Philippe Ariès francia történész 1987-ben napvilágot látott, magyarul a „Gyermek, család, halál" címen megjelent tanulmánya szerint a középkori ember számára a gyermekkor nem volt több egy értéktelen átmenetnél, egy szükséges, elkerülhetetlen, ám semmiképp sem fontos vagy becsben tartott időszaknál a felnőtté válás folyamatában. Úgy gondolta, hogy a magas gyermekhalandóság miatt az anyák nem alakítottak ki szoros kapcsolatot gyermekeikkel, nem voltak fogékonyak a gyermeki sajátosságok iránt, feléjük irányuló érzelmeiket leginkább a közöny jellemezte. Ez a távolságtartó magatartás mintegy védőburokként 
szolgált a nagyon gyakori gyermekhalandóság okozta megrázkódtatás ellen, túlélő eszközként egy olyan korban, ahol mindennapos volt a gyermekek elvesztése. Ariès véleménye szerint (Ariès, 1987) a közöny a védekező mechanizmus részeként lehetővé tette a középkori szülőknek, hogy feldolgozzák és együtt éljenek a mindennapos gyermekhalál árnyékával. A gyermekek védett világa, mint olyan, nem létezett. A bizonytalan csecsemő- és kisgyermekkort túlélő gyerekek a felnőttek társadalmának tagjai lettek, felnőttként kezelték őket. Szemük előtt zajlottak az élet jó és rossz mozzanatai: szülés, szenvedés, halál, szexuális élet. A felnőttek mindennapi életének részeseivé váltak, első kézből tapasztalták és ismerték meg az életet, annak minden árnyoldalával együtt.

Nézetének egyik legfontosabb követője az amerikai Edward Shorter, aki azonban amellett, hogy egyetért Ariès nézőpontjával, túl is lép azon. Az igen magas gyermekhalandóságot nem a felnőttek gyermekek szembeni attitüdjének okaként, hanem annak következményeként kezeli (Shorter, 1975). Véleménye szerint a szülők nem azért nem kötődtek gyermekeikhez, hogy távolságtartásukkal felvértezzék magukat a gyakori csecsemőhalandóság okozta fájdalommal szemben, hanem éppen ellenkezőleg. A gyermekhalandóság igen nagy arányát a szülők érdektelen, elhanyagoló, szeretetet, törődést és gondoskodást nélkülöző hozzáállása okozta. Sőt, a tragédiák mögött gyakran szándékos, tudatos, a gyermek élete feletti döntéshozatal állt, melyhez egyszerü eszközöket használtak, például túl korai elválasztást, tudatos elhanyagolást, helytelen táplálkozást vagy alkohollal, ópiummal való nyugtatást (Shorter, 1975).

Shulamith Shahar tanulmánya (Shahar, 2000) szerint azonban veszélyes dolog mai szemmel megítélni és elítélni a középkori gyermekszemléletet. Véleménye szerint fontos, hogy a gyermekekkel szembeni attitüdöt mindig az adott korra jellemző szokásoknak, elvárásoknak, társadalmi viszonyoknak megfelelően értelmezzük. Elismeri azt, hogy a középkorban alkalmazott gyermekgondozási, -nevelési szokások sokszor felfoghatatlannak, értelmetlennek, sőt drasztikusnak hatnak, de óva int attól, hogy mindezekből azt a következtetés vonjuk le, hogy a középkori társadalomban nem volt értéke a gyermeknek. Úgy véli, hogy a szülők szeretettel, gondoskodással nevelték gyermekeiket, de tették mindezt az adott korra jellemző mentalitásnak, a rendelkezésükre álló tudásnak, gyógyászati ismereteiknek és higiéniai színvonalnak megfelelően. A gyermekekkel szembeni attitűdöt nagymértékben meghatározta a középkor uralkodó hit- és értékrendszere, illetve a gazdasági feltételek. „Gyermekek a középkorban" című könyvének központi tétele szerint a csecsemő és gyermekhalandóság igen magas arányát nem a középkori szülők érzelmi távolságtartása okozta, annak hátterében a szűkös táplálkozás, a higiénia hiánya, a járványok, illetve az orvosi ismeretek korlátozott szintje állt. Cselekedeteiket, a gyermekekhez füződő viszonyukat nem a rossz szándék vezérelte, gondoskodtak róluk, gyermekként kezelték őket, nevelési normákat alkalmaztak (Shahar, 2000).

A gazdag forrásanyagból dolgozó, korabeli angol és amerikai naplókat elemző Linda Pollock a feltárt információkra támaszkodva ellentmond Ariès azon tézisének, hogy a középkorban nem létezett gyermekfelfogás. Véleménye szerint a szülők felismerték a gyermekek gyermekies voltát, hogy gondoskodásra, védelemre szorulnak, hogy fegyelmezéssel, neveléssel kell őket irányítani, és hogy fejlődési szakaszokon mennek keresztül (Pollock, 1983). Az általa feldolgozott, rendkívül nagyszámú naplóleírásból egyértelmüen kitűnik, hogy a gyermekeket fejlődő szervezetnek tekintették, felismerték fogékonyságukat a külső hatásokra. A gyermekekkel szembeni attitűdöt ambivalencia jellemezte, szüleiknek egyszerre jelentettek örömet és bosszúságot, szórakozást és aggodalmat. Pollock véleménye szerint (Pollock, 1983) szoros szálak füzték őket gyermekeikhez, büszkék voltak eredményeikre, gyötrelmet jelentett, ha megbetegedtek, élvezték a velük való együttlétet és elég fontosnak tekintették őket ahhoz, hogy átgondolt döntéseket hozzanak velük kapcsolatban. Közömbösek azonban nem voltak irányukba. Az általa tanulmányo- 
Középkori gyermekgondozási szokások és eszközök...

zott naplóleírásokból egyértelműen kitűnik, hogy a szülőket felzaklatta gyermekük betegsége, a gyakori gyermekhalandóság nem tette őket közömbössé, épp ellenkezőleg, fokozta aggodalmukat. Tisztában voltak azzal, hogy egy sima megfázás is rosszul végződhet, páni félelem, álmatlan éjszakák, a halál fenyegető közelsége miatt érzett aggodalom jellemezte érzelmeiket beteg gyermekük iránt. Annak elvesztése esetén pedig gyötrelmes kínokat éltek át (Pollock, 1983).

A nagy számban rendelkezésre álló, rendkívül részletgazdag korabeli képzőművészeti alkotások lehetőséget adnak arra, hogy bepillantást nyerjünk a csecsemők és kisgyermekek életébe, megismerjünk olyan szokásokat, melyek napjainkra már kimentek a gyakorlatból, de korunk egyes eszközeinek középkori elődeivel is találkozhatunk.

Nem célom ezen alkotások művészettörténeti elemzése. Kutatásom célkitűzése az volt, hogy a fellelhető festmények közül szemezgetve kiválogassam azokat, melyekből levonhatók bizonyos, a kor gyermekszemléletére utaló jegyek, illetve amelyeken gondozási eszközök, szokások jelennek meg.

Bár a középkori képzőművészeti alkotások is bizonyos elvárások, trendek alapján készültek és tükrözik alkotóik szemléletmódját, a rendelkezésünkre álló, különböző kultúrájú, nézőpontú és stílusú művészektől származó alkotások nagy száma valamely mértékben bepillantást enged ezen kor hétköznapjaiba, feltárva előttünk a kisgyermekek életének egyes mozzanatait. Igyekeztem minél több festő munkáját megismerni, ezáltal többféle nézőponton, szemléleten és stíluson keresztül bemutatni a középkori gyermekábrázolást. Az egyediségükben egymástól eltérő művek felkutatása során sokszor tapasztaltam hasonló jegyek megjelenítését ezen alkotásokon, mely a korra jellemző szokásokra, bevett gyakorlatokra enged következtetni.

\section{Pólyázás, bölcső}

Számos olyan alkotásra bukkantam, mely bölcsőben fekvő kisgyermeket ábrázol, aki valamilyen tevékenységet végző édesanyja vagy a gondozásával megbízott személy közelében, annak figyelő tekintete mellett alszik (1. és 2 . ábra). Ezek az eszközök legtöbbször fonott kosárkák voltak, ívesen kialakított lábuk lehetővé tette a ringatást. A kosár felső része a kisgyermek feje fölé emelkedett, amelyre szükség esetén sötétítőként funkcionáló anyagot borítottak. A kisgyermekek fejét és felsőtestét párnákkal magasan megemelték. Az 1. ábrán jól látszik, ahogy az édesanya egy a bölcsőhöz kötözött madzag segítségével ringatja álomba gyermekét. A felsőbb osztálybeli családok kisdedeinek bölcsői valószínűleg fából készültek, kialakításuknál a funkcionalitás mellett fontos szerepet kapott a dekoratív megjelenés is. A 3. ábrán látható család rangjának megfelelően a csecsemő bölcsője is motívumokkal ékes, díszítésekben gazdag.
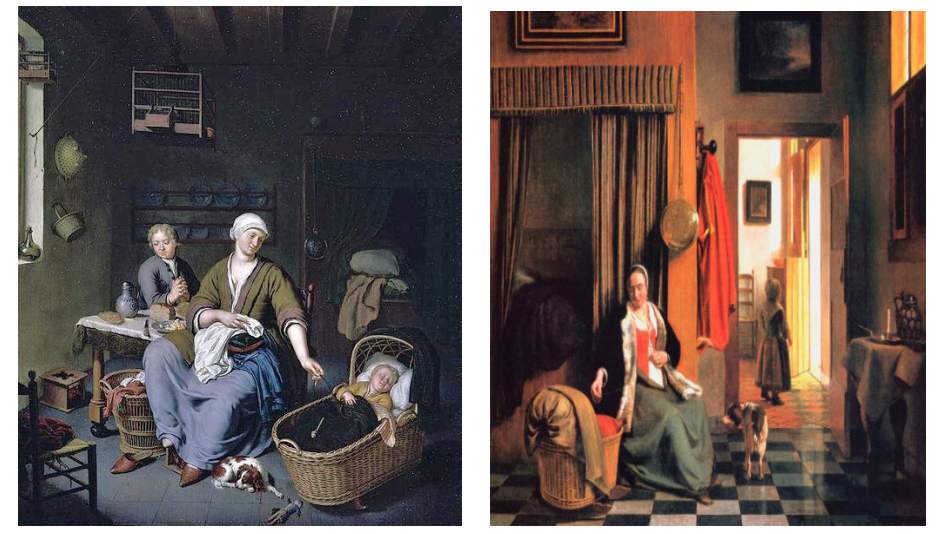

1-3. ábra

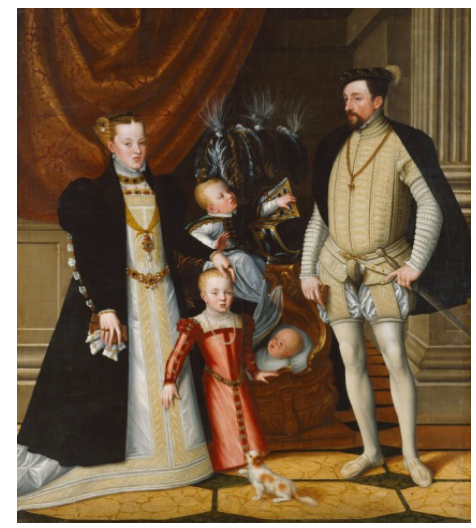


A középkor gondozási szokásait bemutató szakirodalomban a szerzők többször is említést tesznek a csecsemők szoros pólyázásáról. Ezen gyakorlat nem a kisdedek mozgásának korlátozására, sokkal inkább azok rögzítésére szolgált, illetve melegen tartotta őket. A csecsemők puha, a kor szemlélete szerint viaszszerű testét pólyával szorosan átkötve igyekeztek az elvárt formának megfelelőre alakítani (Shahar, 2000).

A lenti képeken a pólyázás gyakorlatára láthatunk példákat. A 4. és 5. ábrán jól megfi- gyelhető, hogy a pólyázáshoz használt anyaggal a csecsemő karjait is szorosan a testéhez kötözték, nem sok lehetőséget hagyva a mozgásra, de biztosítva testformájának megfelelő alakulását (Shahar, 2000). A 6. és 7. ábrán megjelenített kisgyermekek társadalmi helyzetét jól jelzi ruházatuk, még a pólyázásához használt anyag is a család rangjának megfelelő. Itt is megfigyelhető a szépen kidolgozott fa bölcső, a párnákkal magasan megemelt testhelyzet.
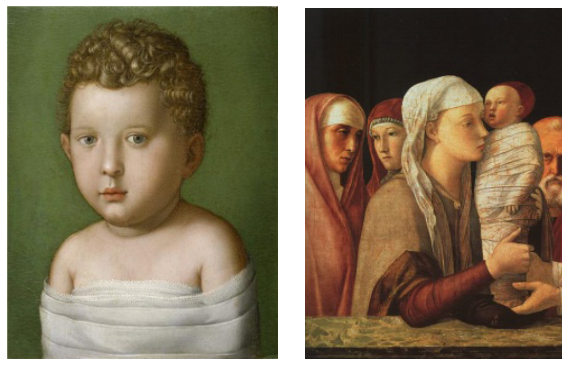

\section{Szoptatás, dajkaság}

Rendkívül nagy számban bukkantam olyan középkori képzőművészeti alkotásra, amelynek témája a szoptatás. Más témájú festmények részleteként is nagyon gyakran felbukkan. Egyes müvek szoptató édesanyákat ábrázolnak, alsó és felső osztálybeli asszonyok is megjelennek kisdedeikkel. A 8. ábrán látható háromgyermekes édesanya bizonyára megengedhetné magánk, hogy szoptatós dajka lássa el legkisebb gyermekét, gondoskodó szeretetét jelzi, hogy mégis saját maga táplálja. A 9. ábrán
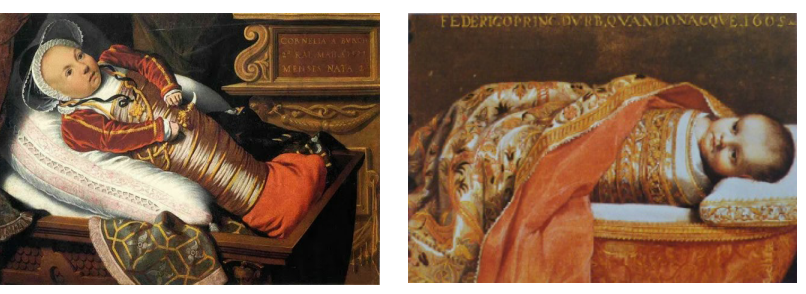

4-7. ábra

nemcsak az anya, de egy neki segítő szolgáló is megjelenik, aki a ház körüli teendőkben nyújt segítséget, vizet hoz. A kisgyermek táplálását azonban maga az édesanya végzi. A 10. ábrán megjelenő mű meghittséget áraszt, az asszony áhítattal tekint a kisdedre, nagyobb gyermeke a közelében ül. Az ablakon beszűrődő fény melegséggel árasztja el a szobát, mintegy tovább növelve a szoptatás idilli képét.

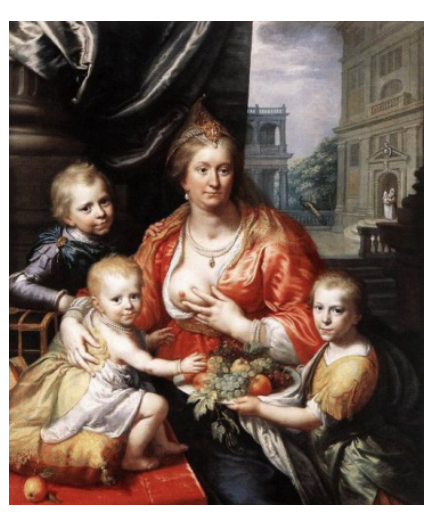

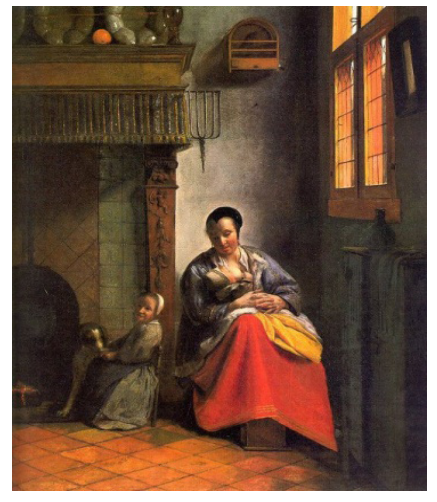

8-10. ábra 
Középkori gyermekgondozási szokások és eszközök...

Az édesanyák mellett dajkák is megjelennek számos alkotáson. A szoptatós dajkaság intézménye korunkban már nem létezik, de magától értetődő intézménynek tekintették a középkorban, gyakorlata egészen a pasztörizálás elterjedéséig jelen volt (Shahar, 2000). A magas gyermekhalandóság miatt az asszonyok igyekeztek minél több utódot világra hozni, a gyakori gyermekvállalás azonban nem tette lehetővé megfelelő ideig tartó szoptatásukat. Gyermekeik táplálását, ezáltal pedig jól-létét szem előtt tartva a dajka által történő szoptatásban találták meg a megoldást, és hittek abban, hogy ezen gyakorlat a gyermekek érdekét szolgálja (Endrődy-Nagy, 2013; 2015).

Az életük első időszakát szoptatós dajkáknál eltöltő kisgyermekek az elválást valószínűleg nehezen élhették meg, hiszen el kellett szakadniuk attól a személytől, aki addig gondozásukat, táplálásukat végezte, így vagy úgy, de gondoskodott róluk. Az elválás és egy ismeretlen anyához történő kerülés fájdalmát mutatja be a 11 . ábra. A ragaszkodás nem egyoldalú, láthatóan a dajka is nehezen tud megválni a gyermektöl. Vitathatatlanul jobb helyzetben volt az a gyermek, akinek tehetősebb szülei megengedhették maguknak, hogy dajkát fogadjanak a házukba. Így lehetőségük volt figyelemmel kísérni gyermekük megfelelő táplálását és fejlődését, a gyermeknek pedig nem kellett osztozkodnia másokkal az anyatejen (Shahar, 2000). A 12. ábra egy édesanyát ábrázol, aki kényelmes körülmények között fürdőt vesz, a háttérben látható szolgáló gondoskodik meleg fürdővízéről. Az anya közelében a dajka a szoros pólyába burkolt kisgyermeket táplálja. Míg az anya ábrázolásában a művész a fiatalságot és üdeséget emeli ki, a dajka legszembetűnőbb tulajdonsága a gyermek megfelelő táplálásával áll összefüggésben.

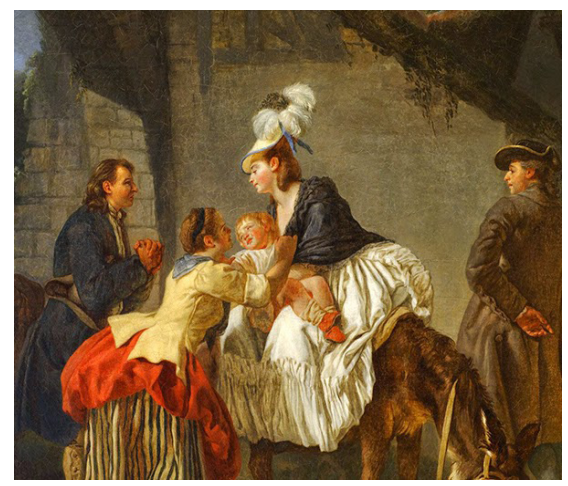

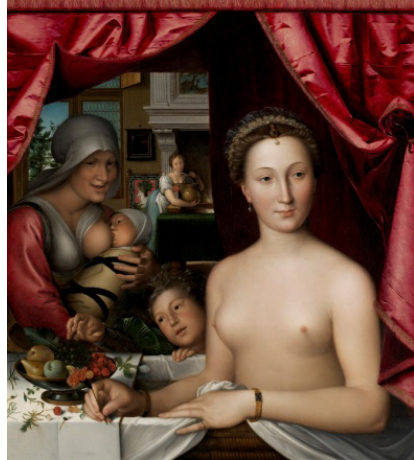

11-12. ábra

A szoptatós dajkák fontos szerepét szemlélteti az is, hogy az anya-gyermek ábrázolások mellett születtek olyan alkotások is, melyeken a kisgyermek dajkájával jelenik meg, édesanyja nélkül. A lenti képeken szinte érezhető a kettejük közti meghitt kapcsolat (13. és 14. ábra). Ezeket a személyeket a kisgyermek életének rendkívül fontos szereplőjének tekintették, különben nem lettek volna megörökítve így együtt, ilyen meghitt módon.
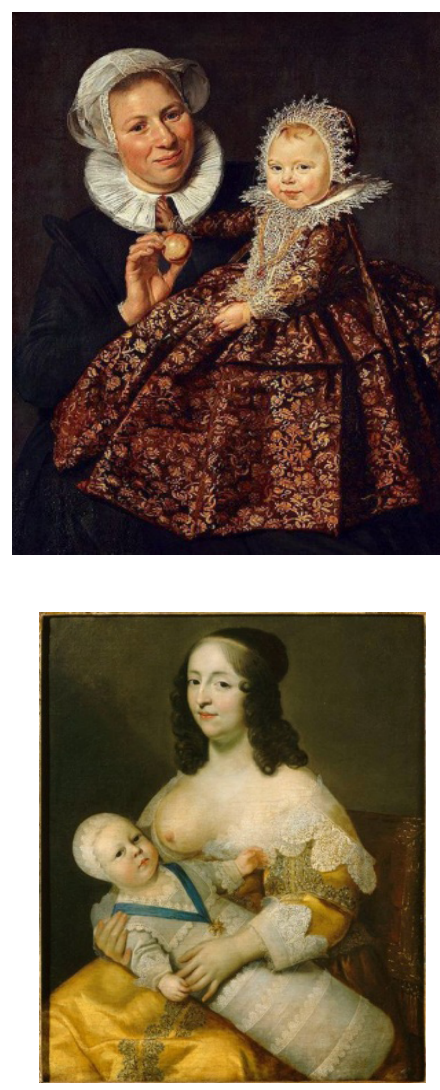

13-14. ábra 


\section{Zajkeltő és fogzáskönnyítő eszközök}

A középkori szülők valószínűleg tisztában voltak a fogzást kísérő fájdalommal és nyugtalansággal. A kisgyermekek megnyugtatására és figyelmének elterelésére már akkoriban is használtak csörgőket. Ezeket általában valamilyen fogzáskönnyítő eszközzel kombinálták, így többfunkciós tárgyként működtek. Az általam fellelt, csörgőket is ábrázoló alkotásokon többnyire felsőbb osztálybeli gyermekek láthatók, így a szegényebb réteg által használt zajkeltő és fogzáskönnyítő eszközök megfigyelésére nem volt módom. Feltételezni tudom csupán, hogy a lent bemutatásra ke- rülő eszközökkel szemben egyszerübb anyagokból és módon létrehozott változatokat használtak, de akár egy mákgumó is megfelelhetett a célnak. A korábban bemutatott gyermekgondozási eszközökhöz hasonlóan a magasabb rangú családok itt is törekedtek arra, hogy szépen kidolgozott, nemes anyagokból készült csörgőt adjanak gyermekeik kezébe. Az eszköz felső része fogzáskönnyítőként funkcionált, ez alatt helyezkedtek el a csörgőként működő kis golyók, melyek sokszor nemesfémből készültek (15., 16. és 17 . ábra). Az eszközt a gyermek hosszú láncon a nyakába vagy derekára akasztva viselte.
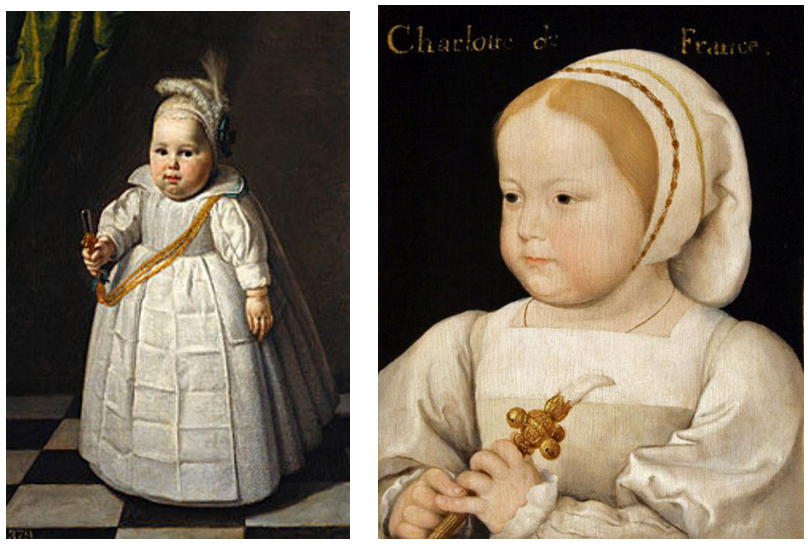

15-17. ábra

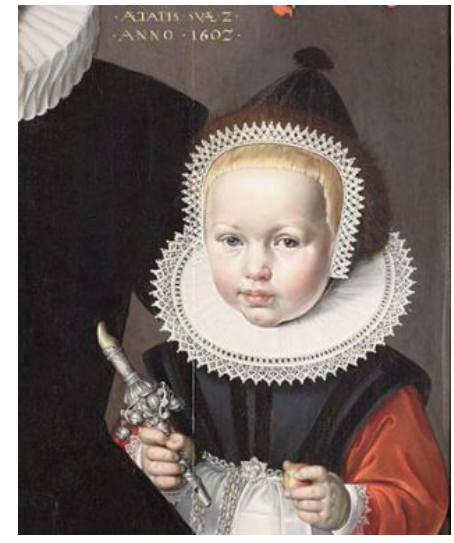

gásukat. A 20. ábrán látható kisfiú csengettyüvel és a ruhája anyagából készült, annak részét képező pánttal is rendelkezik, melyet édesanyja tart a kezében. Ilyen pántokat rendkívül sok alkotáson volt módom megfigyelni, nemre való tekintet nélkül képezték részét a gyermekek ruházatának egészen addig, míg el nem érték a 6-7 éves kort, amikortól is a felnőtt társadalom részévé váltak és öltözetükből is eltűntek a gyermekkorra utaló jelek (Shahar, 2000). zelükben tudni, illetve kantárszerủen kézben tartva felügyelni, irányítani helyváltoztató moz-
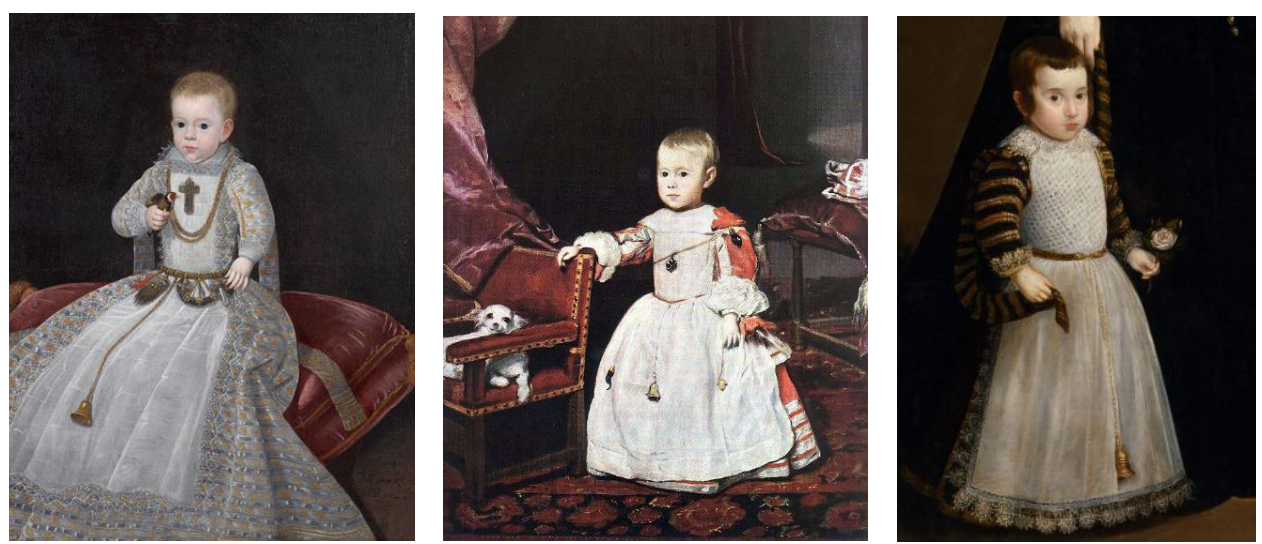
Középkori gyermekgondozási szokások és eszközök...

\section{Járássegítő eszközök, etetőszék}

Az 21. ábrán megfigyelhető járássegítő eszköz megakadályozza a még nem stabilan álló és járó kisgyermek esetleges felbukását. Az eszköz alján lévő kerekek lehetővé teszik a helyváltoztató mozgást, miközben a váz biztonságos keretként nyújt védelmet a kisgyermek számára. A fából készült eszköz szépen megmunkált, motívumokkal díszített, jelezvén, hogy nemcsak a funkcionalitása volt fontos, hanem esztétikus megjelenése is. A 22. ábrán jól látható, hogy hátsó részének kialakítása lehetővé tette egy másik személy által történő irányítását, segítve a haladást. Ezen eszköz azonban korlátok közé szorította a gyermeket, akadályozta helyzetváltoztató mozgását, nem tudott benne szabadon mozogni, lehetetlen volt benne leülni, leguggolni vagy akár lehajolni valamiért. A 23. ábrán megjelenő járássegítő eszköz már kevésbé szorosan öleli körül a kisgyermek derekát, nagyobb teret enged. Itt a háttámla magas kialakítása véd az eséstől. Párnázott kialakítása egyrészt megóvja a gyermeket attól, hogy kemény részeiben megüsse magát, másrészt esztétikai szerepet tölt be.
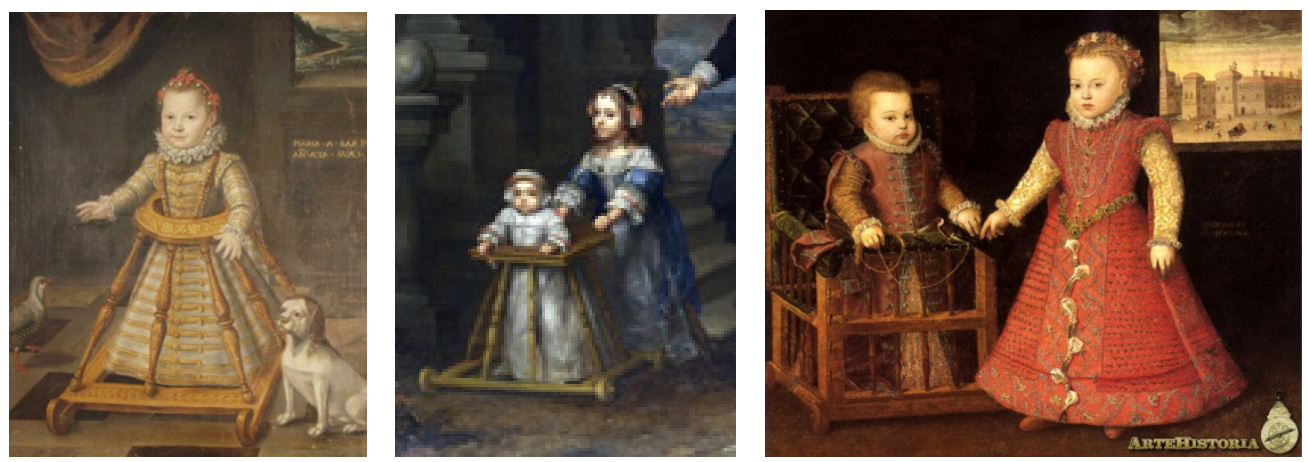

21-23. ábra

A 24. ábrán látható eszköz már kerekek nélkül került kialakításra, inkább csak az állást segíti, illetve helyhez köti a gyermeket, hogy biztonságban és szem előtt legyen, míg édesanyja dolgozik. Funkciójának megfelelően ez már kicsit szélesebb peremmel került kialakításra, melyen elhelyezhetők a kisgyermek játékszerei, valószínűleg étkezésre is használták. Ennek az eszköznek egy másik változata a még állni nem tudó kisgyermek biztonságos ültetését teszi lehetővé, a mai etetőszékek szisztémáját fedezhetjük fel benne. Az 25. ábrán kisasztalkával ellátott széket láthatunk, érdemes megfigyelni biztonságos kialakítását. A gyer- mek méreteihez igazodó, őt szinte körülölelő szék magas háttámlája és a fej vonalában két oldalról benyúló fejtámasz biztonságos ültetést tesz lehetővé. Kicsit idősebb, már biztosan ülő gyermekek számára oldaltámasz nélkül és rövidebb háttámlával került kialakításra, itt a biztonságot az elől lévő korlát szolgáltatja. Magas lábainak köszönhetően lehetővé tette, hogy a gyermek a felnőttek asztalánál tudjon étkezni. Itt is megfigyelhető a vastag brokátborítás, mely egyrészt a gyermek kényelmét szolgálja, másrészt az eszköz esztétikus megjelenését hivatott biztosítani (26. ábra).
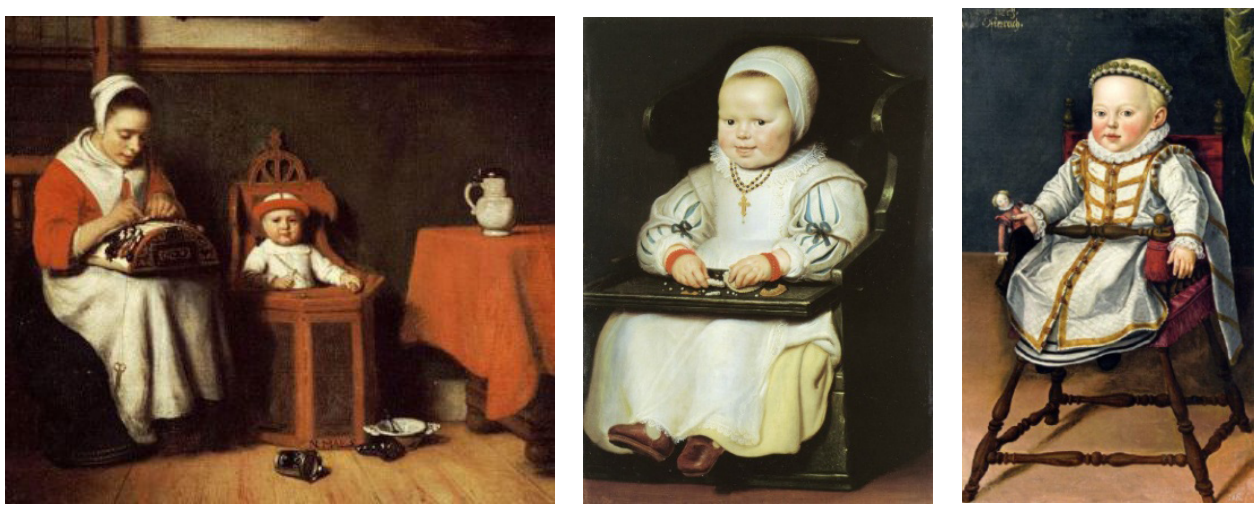


\section{Párnázott fejpánt}

A még instabilan járó, gyakran felbukó totyogók koponyájának védelmét szolgálhatta a fejvédőkét funkcionáló fejpánt. A puha, párnázott eszköz megóvta a kisgyermekek fejét az esetleges sérülésektől (24., 27., 28. és 29. ábra). Ez az eszköz jól szemlélteti, hogy a szülök fontosnak tekintették gyermekeik biztonságát, tettek azért, hogy mérsékeljék a balesetekből fakadó sérülések kockázatát.

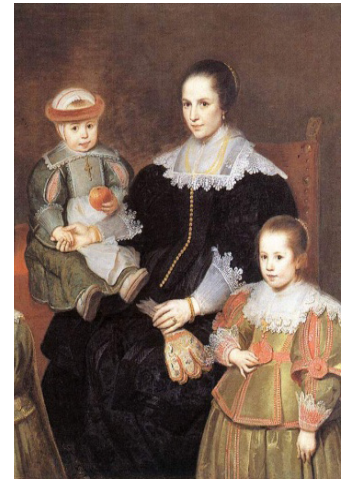

Ruházat

Érdemes megfigyelni, hogyan változott a kisgyermekek ruházata életük első időszakában. A csecsemőkorból kilépve már a felnőttek ruházatával megegyező öltözéket kaptak, azonban a kisfiúk esetében ez nem a felnőtt férfiak által hordott darabokat jelentette. Míg el nem érték a 6-7 éves kort, amikortól is a felnőtt társadalom tagjaiként tekintettek rájuk (Shahar, 2000), a kisfiúk és kislányok ruházata szinte teljesen megegyezett. Hacsak erre a mű címe nem tesz utalást, sok kora-
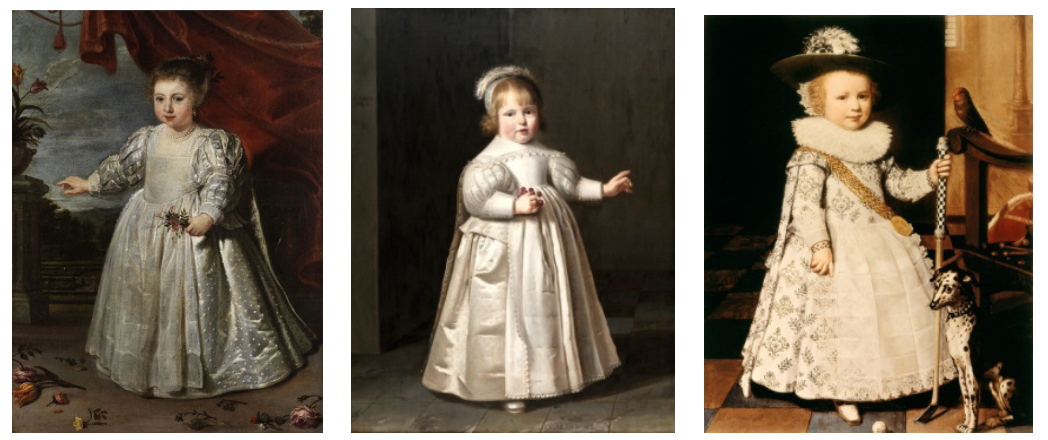

30-33. ábra

Ekkor még részét képezik öltözetüknek azok a ruha vállrészéhez varrt pántok, melyek a felnőttek által történő irányításra, mozgásuk kontrollálására szolgáltak (30., 31. és 32. ábra). A 6-7 éves kort elérve a gyermekek már fiatal felnőttnek számítottak és ez a kisfiúk ruházatán is megmutatkozott. Ettől kezdve már a férfiak öltözködési szokásait követték és megjelené-

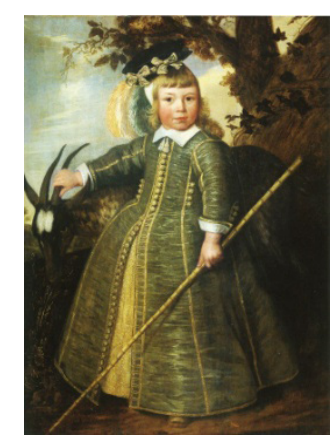

beli műalkotás esetében nehézséget okoz az ábrázolt kisgyermek nemének megállapítása. Ezen szokás hátterében gyakorlati okok húzódhattak meg. A szobatisztaság elsajátítását, kis- és nagydolguk elvégzését pedig rendkívül megkönnyítette, hiszen nem kellett csatokkal küszködniük, elég volt csak megemelni ruhájukat, nem beszélve arról, hogy sokkal egyszerübb volt a ruha hosszát a gyorsan növekvő gyermekhez igazítani. Az 30. ábrán egy kislányt láthatunk, az 31., 32. és 33. ábrákon pedig megfigyelhetjük, mennyire hasonló öltözéket hordtak a korabeli kisfiúk.

süknek megfelelően felnőttekhez méltó viselkedést vártak el tőlük (Shahar, 2000). Az 34. és 35. ábrán látható fiúk ruházatából és testtartásából szinte férfias magabiztosság árad. A kisgyermekkorból kilépő lányok ruházata nem változott jelentősebben, viszont ettől fogva öltözetük részét nem képezték a ruhákra varrt vállpántok (36. ábra). 

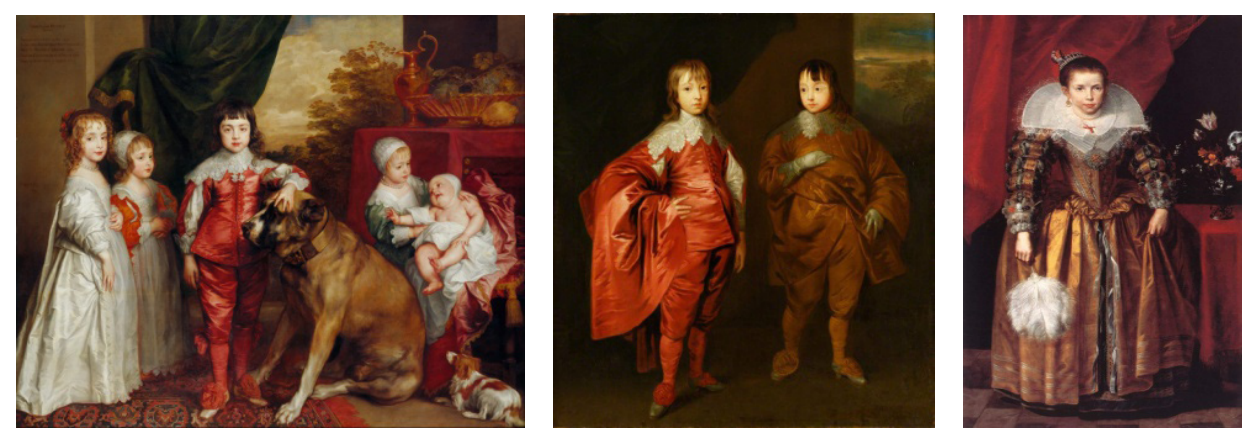

34-36. ábra

\section{A képzőmüvészeti alkotások által tükrözött gyermekszemlélet}

A 21. századtól nemcsak időben, de világnézetét, szokásait és attitűdjeit tekintve is távol eső kor gyermekszemléletéről kialakult, egymástól sok esetben igencsak eltérő nézeteket valló szerzők írásait tanulmányozva lehetetlen feladatnak bizonyult annak pontos, egyértelmü meghatározása, hogy a középkorban milyen lehetett a szülö-gyermek kapcsolat, hol volt a gyerekek helye a családokban és hogyan viszonyult hozzájuk a társadalom. Ugyan a járványokkal, háborúkkal és éhínséggel sújtott korban nem lehetetett könnyü a gyermekek élete, mégsem tekinthetjük a társadalom, a szülők velük kapcsolatos hozzáállását egységesen negatívnak. Úgy gondolom, hogy ha sikerül elvonatkoztatnunk a mai normáktól, megkísérelhetjük a középkor szellemiségén keresztül szemügyre venni annak gyermekszemléletét, a szülő-gyermek kapcsolatokat és gondozási szokásokat, nem tévesztve szem elől a középkori társadalom rendelkezésére álló higiéniai és gyógyászati ismereteinek eléggé korlátozott szintjét.

Egyes szerzők véleményével ellentétben úgy gondolom, hogy a felnőttek attitűdje nem közönyös, távolságtartó vagy ellenséges volt, csupán más, mint napjainkban. Véleményem szerint a szülők tudásuknak, a kor egészségügyi ismereteinek, világnézetének és értékrendjének megfelelő módon viszonyultak gyermekeikhez és hittek abban, hogy cselekedeteik, szokásaik helyesek.

Kutatásom során számos olyan tárggyal találkoztam, mely a gyermek biztonságát, kényelmét, megnyugtatását volt hivatott biz- tosítani vagy egyszerűen csak jóleső érzést, örömöt szerzett kis tulajdonosának. Mindez pedig arra enged következtetni, hogy a felnőttek tisztában voltak a gyermekkor sajátos vonásaival és igyekeztek megfelelő módon gondoskodni utódaikról, akik fontos részét képezték életüknek.

\section{Felhasznált irodalom}

Ariès, P. (1987): Gyermek, család, halál. Gondolat, Budapest.

Endrődy-Nagy Orsolya (2013): Középkor és reneszánsz. Adalékok egy lehetséges gyermekképi paradigmaváltáshoz. Gyermeknevelés, 1. 1. szám, 63-72.

URL: http://gyermekneveles.tok.elte.hu/1_szam/ Endrody_kozepkor.pdf (letöltve: 2015.01.10)

Endrődy-Nagy Orsolya (2015): A reneszánsz gyermekképe - a gyermekkép reneszánsza 1455-1517 között Európában - ikonográfiai elemzés, doktori disszertáció, Eötvös Kiadó, Takács Etel Pedagógiai Alapítvány, Budapest.

Golnhofer Erzsébet és Szabolcs Éva (2005): Gyermekkor: nézópontok, narratívák. Eötvös József Könyvkiadó, Budapest.

Mucsiné Isaszegi Irina (2015): Gyermeknek lenni a sötét (?) középkorban, szakdolgozat, ELTE TÓK.

Pollock, L. (1983): Forgotten children. Parentchild relations from 1500 to 1900. Cambridge University Press, London-New York.

Pukánszky Béla (2001): A gyermekkor története. Müszaki könyvkiadó, Budapest.

Shahar, S. (2000): Gyermekek a középkorban. Osiris Kiadó, Budapest.

Shorter, E. (1975): The making of the modern family. Basic Book, Inc. Publishers, New York. 


\section{Felhasznált ábrák jegyzéke}

1. ábra:

Willem van Mieris (1728): Interior with a mother attending her children. Olaj, tábla, $45 \mathrm{x}$ $38 \mathrm{~cm}$, magángyüjtemény része.

URL: http://commons.wikimedia.org/wiki/ File:Mieris,_Willem_van_-_Interior_with_a_ Mother_Attending_her_Children_-_1728.jpg (2014.12.21.)

2. ábra:

Pieter de Hooch (1659-60): Mother lacing her bodice beside a cradle. Olaj, vászon, 92 x 100 $\mathrm{cm}$, Staatliche Museen, Berlin.

URL: http://www.wga.hu/html_m/h/hooch/2/ (2014.12.21.)

3. ábra:

Giuseppe Arcimboldo (1563): Maximilian II, his wife and three children. Olaj, vászon, $240 \mathrm{x}$ $188 \mathrm{~cm}$, Kunsthistorisches Museum, Bécs.

URL: http://commons.wikimedia.org/wiki/ File:Giuseppe_Arcimboldo_-_Maximilian_II,_ His_Wife_and_Three_Children_-_WGA0797.jpg (2015.01.05.)

4. ábra:

Agnolo Bronzino (1540-49): Portrait of a baby boy. Olaj, vászon, 33,5 x $26 \mathrm{~cm}$, Walters Art Museum, Baltimore.

URL: http://commons.wikimedia.org/wiki/ File:Workshop_of_Agnolo_Bronzino___Portrait _of_a_Baby_Boy_-_Walters_37451.jpg (2015.01.05.)

5. ábra:

Andrea Mantegna (1455): Presentation at the temple. Részlet. Tempera, vászon, 68,9 x 86,3 $\mathrm{cm}$, Gemäldegalerie, Berlin.

URL: http://en.wikipedia.org/wiki/Presentation at_the_Temple_\%28Mantegna\%29 (2014.12.22.)

6. ábra:

Ismeretlen festő (1581): Portrait of Cornelia Burch aged two months. Olaj, vászon, $54 \mathrm{x}$ $77,5 \mathrm{~cm}$, Ferens Art Gallery, Hull.

URL: http://www.vads.ac.uk/large.php?uid=87111 (2015.01.05.)

7. ábra:

Federico Barocci (1605): The swaddled Prince of Urbino in the cradle.

URL: http://commons.wikimedia.org/wiki/ File:Der-gewickelte-Prinz.JPG (2015.01.09.)

8. ábra:

Paulus Moreelse (1621): Sophia Hedwig, countess of Nassau Dietz, with her three sons. Olaj, vászon, Rijksmuseum, Het Loo Palace, Appeldorn.
URL: http://www.wga.hu/html_m/m/moreelse/ sophia_h.html (2015.01.05.)

9. ábra:

Pieter de Hooch (1670-75): Suckling mother and maid. Olaj, vászon, $64 \times 76 \mathrm{~cm}$, Kunsthistorisches Museum, Bécs.

URL: http://www.the-athenaeum.org/art/list. php?m=a\&s=tu\&aid=4920; (2014.12.22.)

URL: http://european-art.findthedata. com/l/14340/Suckling-Mother-and-Maid (2014.12.22.)

10. ábra:

Pieter de Hooch (1658-60): A woman nursing an infant with a child and a dog. Olaj, vászon, 68 x $56 \mathrm{~cm}$, Fine Arts Museums of San Francisco, San Francisco.

URL: http://www.wga.hu/html_m/h/hooch/2/ (2014.12.22.)

11. ábra:

Étienne Aubry (1777): Farewell to the nursemaid. Részlet. Olaj, vászon, $52 \times 63 \mathrm{~cm}$, Puskin Múzeum, Moszkva.

URL: http://www.bridgemanimages.com/en-GB/ asset/188712/aubry-etienne-1745-81/farewell-tothe-nursemaid-1777-oil-on-canvas (2014.12.23.)

12.ábra:

Francois Clouet (1570): Lady in her bath. Olaj, tábla, 92,1 x 81,3 cm, National Gallery of Art, Washington.

URL: http://commons.wikimedia.org/wiki/File: Fran\%C3\%A7ois_Clouet_002.jpg (2014.12.21.)

13. ábra:

Frans Hals (1619-20): Catharina Hooft with her nurse. Olaj, vászon, 68 x 65 cm, Staatliche Museen, Berlin.

URL: http://www.wga.hu/frames-e.html?/html/h/ hals/frans/00-1620/09chilnu.html (2015.01.05.)

14. ábra:

Charles Beaubrun (1640): Portrait of Louis $X I V$ as an infant with his nurse Madame Longuet de la Giraudiere. Olaj, vászon, 81 x 64 $\mathrm{cm}$, Château de Versailles, Versailles.

URL: http://commons.wikimedia.org/wiki/File: Louis_XIV_as_an_infant_with_his_nurse_Longuet _de_la_Giraudi\%C3\%A9re.jpg (2015.01.05.)

15. ábra:

Paulus Moreelse (1634): Portrait of a young boy. Olaj, vászon, 87,5 x $63,3 \mathrm{~cm}$, Royal Collection, Windsor Castle, London.

URL: http://www.royalcollection.org.uk/ collection/404734/portrait-of-a-young-boy (2015.01.14.) 
Középkori gyermekgondozási szokások és eszközök...

16. ábra:

Jean Clouet (1522): Portrait of Madeleine of France, daughter of Francois I and Claude of France. Olaj, tábla, 16,7 x 13,3 cm, magángyüjtemény része.

URL: http://www.weissgallery.com/paintings/ madeleine-france-1520-1537-3rd-daughterfran\%C3\%A7ois-i-1494-1537-and-claudefrance-1499-1524 (2015.01.06.)

17. ábra:

Jan Claesz (1602): Portrait of Albert Fransz. Sonck and his son. Részlet. Olaj, vászon, $122 \mathrm{x}$ $99 \mathrm{~cm}$, Westfries Museum, Hoorn.

URL: https://rkd.nl/en/explore/images/39493 (2015.01.12.)

18. ábra:

Bartolomé Gonzáles (1617-18): Portrait of the infant Don Fernando De Austria. Olaj, vászon, 99 x 79 cm, Szépművészeti Múzeum, Budapest.

URL: http://www.galeriacaylus.com/Bartolom\% C3\%A 9-Gonz\%C3\%A1lez-Valladolid-1564Madrid-1627-Portrait-the-Infant-Don-FernandoAustria-DesktopDefault.aspx?tabid $=6 \&$ tabindex $=$ 5\&objectid=527543 (2015.01.13.)

19. ábra:

Diego Velázquez (1659): Portrait of Prince Philip Prospero. Olaj, vászon, 128,5 x 99,5 cm, Kunsthistorisches Museum, Bécs.

URL: http://en.wikipedia.org/wiki/Portrait_of_ Prince_Philip_Prospero (2014.12.22.)

20. ábra:

Diego Velázquez (1631-32): Dona Antonia de Ipenarrieta y Galdos and her son Don Luis. Részlet. Olaj, vászon, 205 x 115 cm, Museo del Prado, Madrid.

URL: http://en.wikipedia.org/wiki/List_of_works_ by_Diego_Vel\%C3\%A1zquez (2014.12.28.)

21. ábra:

Giovanni Caracca (1595-96): Portrait of Maria Apollonia of Savoy. Olaj, vászon, 112 x $88 \mathrm{~cm}$, Castello di Stupinigi, Torino.

URL: http://www.quirinale.it/qrnw/statico/ artecultura/mostre/2010_8marzo/immagini-html/ do-15.htm (2015.01.17.)

22. ábra:

Gonzales Coques (1664): A family group. Olaj, vászon, 64,2 x 85,5 cm, National Gallery, London.

URL: http://commons.wikimedia.org/wiki/ File:Gonzales_Coques_-_A_Family_Group_ \%281664\%29.jpg (2015.01.17.)

23. ábra:

Alonso Sánchez Coello (1568): Isabel Clara
Eugenia and Catalina Micaela. Olaj, vászon, Monasterio de las Descalzas Reales, Madrid.

URL: http://www.artehistoria.com/v2/obras/ 11031.htm (2015.01.15.)

24. ábra:

Nicolaes Maes (1656-7): The Lacemaker. Olaj, vászon, 45 x $53 \mathrm{~cm}$, Metropolitan Museum of Art, New York.

URL: http://commons.wikimedia.org/wiki/ File:Nicolaes_Maes_-_The_Lacemaker_-_ WGA13819.jpg (2014.12.28.)

25. ábra:

Cornelis de Vos (1627): Portrait of Susanna de Vos. Olaj, tábla, 80 x 55,8 cm, Städelsches Kunstinstitut und Städtische Galerie, Frankfurt. URL: http://commons.wikimedia.org/wiki/File: Cornelis_de_Vos_-_Portrait_of_Susanna_de_Vos.jpg (2014.12.28.)

26. ábra:

Jan Cornelisz. Vermeyen (1577): Portrait of Archduchess Catherine Renata of Austria. Kunsthistorisches Museum, Bécs.

URL: http://commons.wikimedia.org/wiki/File:Ka tharinaRenata\%C3\%96sterreich.jpg (2014.12.28.)

27. ábra:

Cornelis de Vos (1630-35): The family of the artist. Részlet. Olaj, vászon, 144,5 x 203,5 cm, Museum voor Schone Kunsten, Ghent.

URL: http://commons.wikimedia.org/wiki/ File:Cornelis_de_Vos_-_The_Family_of_the_ Artist_-_WGA25307.jpg (2014.12.28.)

28. ábra:

Anthony van Dyck (1620): Portrait of Susanna Fourment and her daughter. Olaj, vászon, National Gallery of Art, Washingon.

URL: http://www.wikiart.org/en/anthony-vandyck/portrait-of-susanna-fourment-and-herdaughter-1620 (2014.12.28.)

29. ábra:

Pieter de Hooch (1672): Interior with a child feeding a parrot. Olaj, vászon, 79,5 x $66 \mathrm{~cm}$, magángyüjtemény része.

URL: http://www.sothebys.com/en/auctions/ ecatalogue/2012/important-old-masterpaintings-n08825/lot.56.html (2014.12.29.)

URL: http://commons.wikimedia.org/wiki/File: Princess_Sophia_Matilda_of_Gloucester_(1773-1844) .jpg (2015.01.11.)

30. ábra:

Cornelis de Vos (17.sz.): Portrait of the artist's daughter. Olaj, vászon, 116 × $85 \mathrm{~cm}$,

URL: http://commons.wikimedia.org/wiki/ File:Cornelis_de_Vos_Portrait_of_his_ daughter.jpg (2015.01.11.) 
31. ábra:

Jan Cornelisz. van Loenen (1634): Portrait of Willem van der Muelen, age 3. Olaj, vászon, 113,6 x 85,7 cm, Landesmuseum, Hannover.

URL: http://www.steigrad.com/van-loenenportrait-of-willem-van-der-muelen/ (2015.01.11.)

32. ábra:

Jan Anthonisz van Ravesteyn (1626): Young boy with a golf club and ball.

URL: http://kolybanov.livejournal.com/9126342. html (2015.01.11.)

33. ábra:

Jan Albertsz. Rotius (1652): Four-year-old boy with goat. Olaj, tábla, $116 \times 87 \mathrm{~cm}$, Rijksmuseum, Amszterdam.

URL: http://www.pubhist.com/w10637 (2015.01.17.)

34. ábra:

Anthony van Dyck (1637): The five eldest children of Charles I. Olaj, vászon, 163,2 x 198.8 cm, Royal Collection, Windsor Castle, London.
URL: http://www.royalcollection.org.uk/collection/ 404405/the-five-eldest-children-of-charles-i (2015.01.17.)

35. ábra:

Anthony van Dyck (1635): George Villiers, 2nd Duke of Buckingham and his brother Lord Francis Villiers. Olaj, vászon, 93 x 85 cm, Royal Collection, Windsor Castle, London.

URL: http://www.wikiart.org/en/anthony-vandyck/george-villiers-2nd-duke-of-buckinghamand-his-brother-lord-francis-villiers-1635 (2015.01.17.)

36. ábra:

Cornelis de Vos (17. század első fele): Portrait of a girl at the age of 10. Olaj, vászon, $94 \mathrm{x}$ $156,5 \mathrm{~cm}$, Galleria Sabauda, Torino.

URL: http://commons.wikimedia.org/wiki/File: Cornelis_de_Vos_-_Portrait_of_a_Girlat_the_ Age_of_10_-_WGA25309.jpg (2015.01.17.)

\section{Medieval child-care practices and devices reflected by contemporary works of art}

The recent decades produced several - sometimes significantly different - trends in regards with the perception of childhood in the Middle Ages. The contemporary parent-child relationship as well as the children's place in the society was defined in many different ways by the experts. By providing insight into the lives of the contemporary infants and children, the highly detailed medieval works of art reflect the attitude towards them. These artworks introduce child-care habits that are no longer part of the modern practice and present some medieval versions of child-care devices used nowadays. During my research I came across a number of paintings portraying object and practices of children's well-being, protection and comfort. I believe this indicates a positive social attitude towards children, highlighting the fact that contemporary adults wanted to ensure that their offspring are properly taken care of.

Keywords: Middle Ages, perceptions of childhood, portrayal of children, childcare, art

Mucsiné Isaszegi Irina (2017): Középkori gyermekgondozási szokások és eszközök korabeli képzőművészeti alkotások tükrében. Gyermeknevelés, 5. 1. sz., 43-54. 